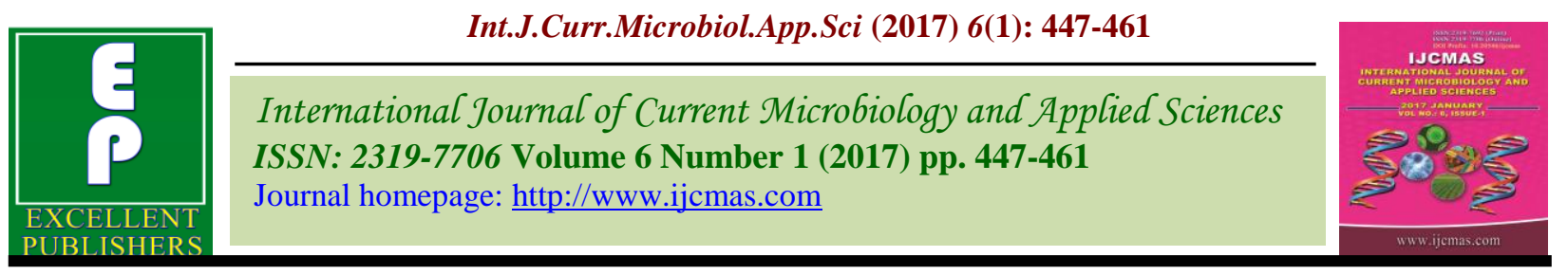

Original Research Article

http://dx.doi.org/10.20546/ijcmas.2017.601.053

\title{
Expression of GSH Gene Related to Heavy Metals Tolerance and Accumulation in Brassica sp. Plant Genotypes
}

\author{
Aysam M. Fayed ${ }^{1}$ and Mona A. Farid ${ }^{2 *}$ \\ ${ }^{1}$ Molecular Biology Department, Genetic Engineering and Biotechnology Research Institute, \\ University of Sadat City, Egypt \\ ${ }^{2}$ Genetics Department, Faculty of Agric., KafrElshikh University, Egypt \\ *Corresponding author:
}

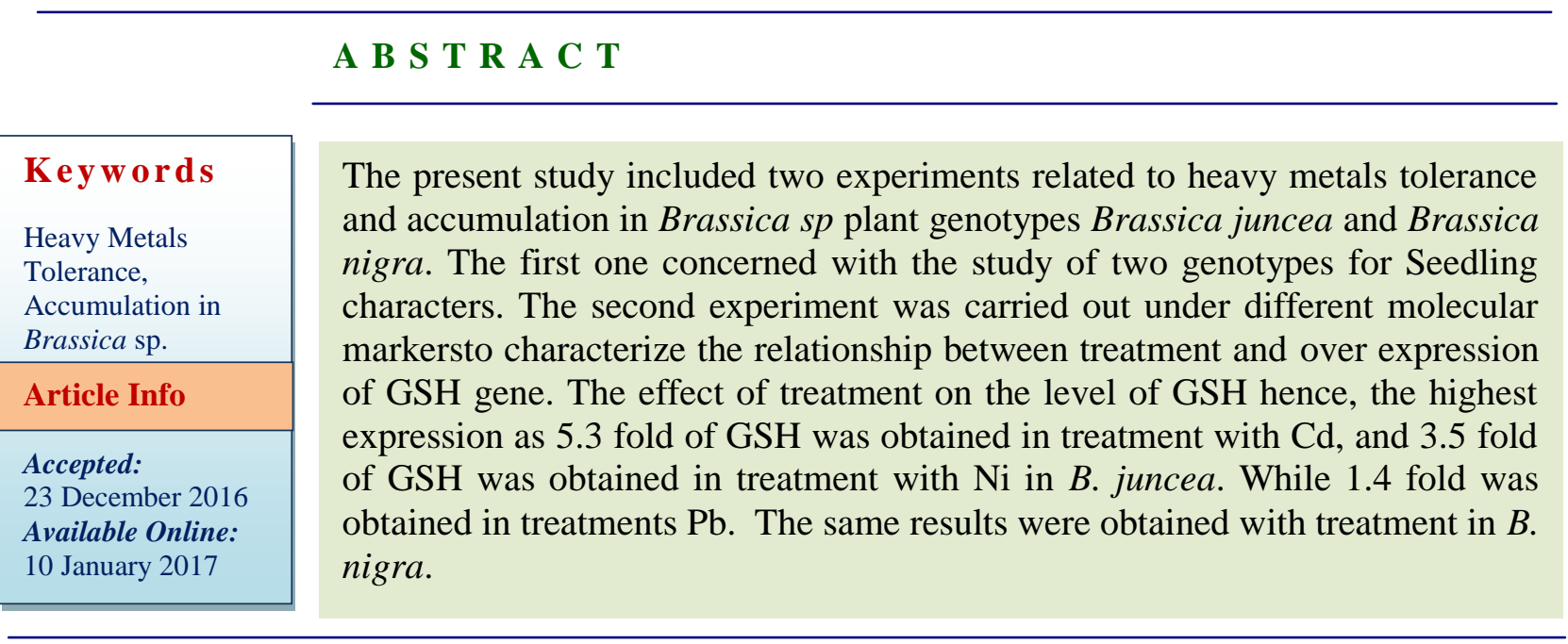

\section{Introduction}

The Brassica genus is very essential agricultural crops in all the world and are also recognized to be heavy metal accumulators. There had been a big number of research regarding the tolerance, uptake and protection mechanism in numerous of those species, considerably Brassica juncea and B. napus, against to the stress caused by heavy metals (Miguel et al., 2015).

Phytoremediation uses green plant to clean up poisonous amount of inorganic and organic pollutants from the environment. The rapid industrialization and urbanization of many evolved and recently growing international locations (as an example China, India, Brazil etc.) have extended heavy metal and natural pollution inside the environment (Memon and Schroder, 2009). Metal infected soils pose an excessive danger to environment, agriculture and therefore thru the meals chain to human and animal health (Schwitzguébel et al., 2011). plants that hyper acquire heavy metals such as $\mathrm{Zn}(2+)$ and $\mathrm{Cd}(2+)$ are currently of notable medical hobby as they can be used for cleaning up contaminated soils, a process known as phytoremediation (Salt et al., (1995); Raskin et al., (1997). Environmental 
pollution from business effluents and other natural pollutants has turn out to be a primary environmental and human situation international (Li and Yi (2012); Dong et al., (2013).

Metals are essential components of all ecosystems and arise evidently inside the earth's crust (Pinto et al., 2003). They appear in a huge variety of oxidative states and coordination numbers, influencing their chemical characteristics and for this reason their bioavailability and toxicity (Pinto et al., 2003; Verbruggen et al., 2009). Positive metals along with iron $(\mathrm{Fe})$, copper $(\mathrm{Cu})$ and zinc $(\mathrm{Zn})$ are taken into consideration vital nutrients to flora and are wished for photosynthesis and as cofactors for many enzymes (e.g. Kovacik et al., 2010; Shanmugam et al., 2011). Plant life soak up vital elements from their environment, however they may be also in a position to accumulate factors, which haven't any recognized organic feature, which include heavy metals like cadmium $(\mathrm{Cd})$, chromium $(\mathrm{Cr})$ or lead $(\mathrm{Pb})$ Peralta-Videa et al., 2009). Those nonessential metals are capable of input plant cells through metallic transporters and vendors for the uptake of crucial metals (Clemens, 2001; Shanker et al., 2005).

Phytoextraction is based on the use of pollutant-accumulating plants for trace element removal from soils by concentrating them in the harvestable parts (Salt et al., 1998). An ideal plant for trace element phytoextraction should possess the following characteristics: (a) tolerance to the trace element concentrations accumulated, (b) fast growth and highly effective trace element accumulating biomass, (c) accumulation of trace elements in the above ground parts, (d) easy to harvest (Vangronsveld et al., 2009). Plant species generate a range of defense mechanisms to resist $\mathrm{Cd}$ induced toxicity and to recover the subsequent damages (Meharg,
1993; Mohamed et al., 2012). Among heavy metals cadmium $(\mathrm{Cd})$, a soil pollutant with a strong toxicity (Waalkes, 2000), inhibits photosynthesis (Qian et al., 2009) and prevents the growth of roots and stem. $\mathrm{Cd}$ inactivates some enzymes by a strong affinity with the thiol group (Mendoza-Cozatl et al., 2005) and it forms the active oxygens such as hydrogen peroxide $\left(\mathrm{H}_{2} \mathrm{O}_{2}\right)$, superoxide anion $\left(\mathrm{O}_{-} 2_{-}\right)$, and hydroxyl radical (_OH) (Romero-Puertas et al., 2004) together with lipid peroxide, causing damage to biopolymer and cell membrane by inducing the oxidative stress (Heyno et al., 2008).

\section{Materials and Methods}

In the present work two species of the Indian mustard were used. The first species (Brassica juncea) was obtained from the Agriculture Research Center (A.R.C.), Giza, Egypt, while the second species (Brassica nigra) was kindly obtained from (IPK), Germany.

\section{Treatments and experimental design}

The experiment was arranged in factorial experiment in Randomized Complete Block Design (RCBD) with three replications. The experiment included two different Indian mustard which were gotten the first species (Brassica juncea), while the second species (Brassica nigra).

Four different concentrations of lead $(\mathrm{Pb})$ i.e. 0, 100, 200 and 400 ppm, cadmium (Cd) i.e. 0, 10, 20 and $40 \mathrm{ppm}$ and nickel (Ni) i.e. 0, 20, 50 and 150 ppm were used. Fifty seeds of uniform size in each cultivar were allowed to germinate to primary roots of $2 \mathrm{~mm}$ length in a Petri dish containing a filter paper of $9 \mathrm{~cm}$ diameter; the Petri dishes were placed in a growth chamber for 7 days at $\pm 28^{\circ} \mathrm{C}$, germinated seeds were selected and transferred to pots (diameter $10 \mathrm{~cm}$ ) 
containing quartz sand. Then, these pots transferred to the green house with day and night temperature of $25^{\circ} \mathrm{C}$ and grown in plastic pots. Seeds were germinated, in the presence of lead $(\mathrm{Pb})$, cadmium $(\mathrm{Cd})$ and nickel (Ni). Each dish contained fifty seeds and a total of three dishes were used for each treatment. After One week from the initiation of germination, selected seedlings (stressed and non-stressed) were carefully transferred to suitable pots containing quartz sand to continue their growth in the greenhouse. They were irrigated with Hoagland's solution, containing macro and micro nutrient. After 21 days of sowing, plantlets were harvested and were homogenized in liquid nitrogen; the plant material was stored in liquid nitrogen until used.

\section{Electrophoresis and isozyme techniques}

Peroxidase (Prx.) E.C.1.111.1.7 was determined by using polyacrylamide gel electrophoresis according to the method of Davis (1964).

\section{SDS Protein Electrophoresis}

SDS - Polyacrylamide gel electrophoresis (SDS-PAGE) was performed according to the method of Laemmli (1970).

\section{Total RNA isolation}

Total RNA was isolated from leaves of both species of the treated and untreated Indian mustard. Plants using the SV Total RNA isolation kit (Promega) according to the technical manual-TM 048.

\section{RT-PCR amplification}

Total RNA was subjected to reverse transcriptase polymerase chain reaction RTPCR by using specific primers for the GSH gene (www.nbci.com). RT-PCR Ready To Go kit (Bio Basic Inc.) was used to isolate the cDNA fragment according to the manufacture system as following:

1- The following reagents were added to the tubes which contained the kitreagents pellet. These reagents contained $1 \mu \mathrm{g}$. of total RNA and $10 \mu \mathrm{M}$ of each specific primer.

5'- CCC GGA TCC ATG GAG TCT TCA AGT CCC - 3'

5'- CCC CTC GAG TTA GCG CTC GAT TTG TAT - 3' a total volume of 50ul.Reaction was completed using nuclease free water.

The PCR conditions were as follows; the tubes were incubated at $42^{\circ} \mathrm{C}$ for 15 minutes to activate the reverse transcriptase enzyme, and $94^{\circ} \mathrm{C}$ for 5 minutes to inactivate the enzyme, then followed by 35 cycles of $94^{\circ} \mathrm{C}$ for $1 \mathrm{~min}, 67^{\circ} \mathrm{C}$ for $1 \mathrm{~min}$, and $72^{\circ} \mathrm{C}$ for $1 \mathrm{~min}$. Finally $72^{\circ} \mathrm{C}$ for 10 minutes.

The PCR products were electrophoresed in $1 \%$ agarose gel. A 100 bp DNA marker was used with the samples and photographed.

\section{Results and Discussion}

The present study for both Indian mustard Brassica nigra and Brassica juncea. study the response of germinate under heavy metals; Lead $(\mathrm{Pb})$, Cadmium $(\mathrm{Cd})$ and Nickel $(\mathrm{Ni})$ stress to confirm the seedling growth performance to examine a range of genetic variability for heavy metals tolerance among both Indian mustard Brassica nigra and Brassica juncea.

\section{Seedling characters}

\section{Lead tolerance evaluation}

The results shown in Table (1) revealed highly significant differences for root/shoot 
ratio $(\mathrm{R} / \mathrm{S})$, germination index (GI), root length (RL), shoot length (SL) and germination \% (FGP) traits between the genotypes and Lead application as well as their interaction.

With respect to root/shoot ratio, significant differences were detected among the two studied Indian mustard species (Table 2).

The species Brassica juncea gave highly significant mean (33.481), while, second species Brassica nigra provide decreased mean (29.456). These differences among two studied Indian mustard species might be attributed to their genetic background.

The analyses of variance indicate that root/shoot ratio was significantly influenced by $\mathrm{Pb}$ application levels. As shown in Table (3), the treatment without $\mathrm{Pb}$ application produced the highly mean of root/shoot ratio (75.449), while the application Lead with 200 $\mathrm{ppm}$ gave the lowest value for root/shoot ratio (6.145). The change in root growth due to the consequences of the exposure of the radical to toxicity and accumulation of metals in the roots followed by slow mobility to the plant shoots (Godzik, 1993 and Fargasova, 1994). According to (Chaignon and Hinsinger 2003), higher concentrations of heavy metals can inhibit root growth before shoot growth and can accumulate in the roots without any efficient increase in its content of the aerial parts. Heavy metals are found to be more toxic for root growth because they accumulate on roots and retard cell division and cell elongation.

\section{Cadmium tolerance evaluation}

The results shown in Table (4) revealed highly significant differences for final germination percentage (FGP), germination index (GI), root length (RL), shoot length (SL) and root/shoot ratio (R/S) traits between the genotypes and $\mathrm{Cd}$ application as well as their interaction.
Regarding to root/shoot ratio, significant differences were detected among the two studied Indian mustard species (Table 5).

The species Brassica juncea gave highly significant mean (35.240), while, second species Brassica nigra provide decreased mean (25.546). These differences among two studied Indian mustard species might be attributed to their genetic background.

The analysis of variance indicates that final germination percentage was significantly influenced by Cadmium application levels. As shown in Table (6), the untreated seedling (control) gave the highly mean value of final germination percentage $(91.88 \%)$, while the application Cadmium with $400 \mathrm{ppm}$ gave the lowest mean for final germination percentage $(68.36 \%)$.

\section{Nickel tolerance evaluation}

In Table (7), the analysis of variance revealed highly significant differences among the genotypes tested for final germination percentage (FGP), germination index (GI), root length (RL), shoot length (SL) and root/shoot ratio (R/S) traits by the genotypes and nickel application as well as their interaction.

Estimates of final germination percentage, significant differences were detected among the studied cultivars (Table 8), Indian mustard species Brassica juncea gave highly significant mean (76.833\%), while Brassica nigra species provide decreased mean (75.00\%).

As shown in Table 9, the untreated seedlings (control) produced the highly mean of final germination percentage $(91.889 \%)$, while the application nickel treated with $150 \mathrm{ppm}$ gave the lowest mean for final germination percentage $(29.611 \%)$. 


\section{Biochemical and Molecular Genetic Analysis}

\section{Isozyme Analysis}

The biochemical methods of investigation, especially isozyme studies, have provided valuable tools for breeders. Isozyme can serve as unique molecular genetic markers for biochemical characterization of genotypes (Tanksley and Orton, 1983). In the present study an attempt was made to assay the variation of number and activity of one isozyme patterns; peroxidase, in the leaves crude extract of three weeks old seedlings. Two varieties; three heavy metals $\mathrm{pb}, \mathrm{Cd}, \mathrm{Ni}$ and three different concentration were chosen for isozymes studies of all the materials. Variations in number and activity of bands are shown in Figures 1, and 2 for the peroxidase.

Figure one of peroxidase isozyme patterns of Brassica juncea as well as their treated with different concentrations of lead, cadmium and nickel. In total, Figure 1 shows a total number of 68 bands detected in the present materials. The untreated genotype showed seven bands as a total. The treated concentration with 40 ppm Cd showed the lowest number of peroxidase isozyme bands ( $\operatorname{Prx} 2$, Prx 3, Prx 4 and Prx 6). While the treated concentration with $200 \mathrm{ppm} \mathrm{Pb}, 20 \mathrm{ppm} \mathrm{Ni}$ and $150 \mathrm{ppm} \mathrm{Ni}$ showed the highest number of bands (Prx 1, Prx 2, Prx 3, Prx 4, Prx 5, Prx 6, Prx 7 and Prx 8). The band (Prx 1) was present in the treated with heavy metals; $200 \mathrm{ppm} \mathrm{Pb}, 20$ $\mathrm{ppm} \mathrm{Ni}$ and $150 \mathrm{ppm} \mathrm{Ni}$ and was absent in the control so, it could be considered as potential markers associated with heavy metals tolerance under treatment. While the band (Prx 5) was present in the control and was absent in 40 ppm Cd, the two bands Prx 7 and Prx 8 were present in the control and were absent in $40 \mathrm{ppm} \mathrm{Cd}$ and $50 \mathrm{ppm} \mathrm{Ni}$.

Figure 2 of peroxidase isozyme patterns of Brassica nigra as well as their treated with different concentrations of lead, cadmium and nickel. In total, Figure 2 shows a total number of 70 bands detected in the present materials. The untreated genotype showed nine bands as a total. The treated concentration with $50 \mathrm{ppm}$ $\mathrm{Ni}$ showed the lowest number of peroxidase isozyme bands $(\operatorname{Prx} 4, \operatorname{Prx} 5, \operatorname{Prx} 6, \operatorname{Prx} 7$ and Prx 9). While the untreated (control) showed the highest number of bands (Prx 1, Prx 2, Prx 3, Prx 4, Prx 5, Prx 6, Prx 8, Prx 9 and Prx 10). The band (Prx 7) was present in the treated with heavy metals; $200 \mathrm{ppm} \mathrm{Pb}, 400$ ppm Pb, 10 ppm Cd, 20 ppm Cd, 40 ppm Cd, $20 \mathrm{ppm} \mathrm{Ni}, 50 \mathrm{ppm} \mathrm{Ni}$ and $150 \mathrm{ppm} \mathrm{Ni}$ and was absent in the control and $100 \mathrm{ppm} \mathrm{Pb}$ so, it could be considered as potential markers associated with heavy metals tolerance under treatment. While the bands (Prx 1 and Prx 2) were present in the control and were absent in their treated with some heavy metals; 100 ppm $\mathrm{Pb}, 200$ ppm $\mathrm{Pb}, 400$ ppm $\mathrm{Pb}, 10$ ppm $\mathrm{Cd}, 20 \mathrm{ppm} \mathrm{Cd}, 40 \mathrm{ppm} \mathrm{Cd}, 20 \mathrm{ppm} \mathrm{Ni}$ and $50 \mathrm{ppm}$ Ni.

The activity of isoenzyme in the two cultivars genotypes treated with heavy metals $(\mathrm{Pb}, \mathrm{Cd}$ and $\mathrm{Ni}$ ) and control determined electrophoretically the intensity of activity of the peroxidase. Results summarized in Figure 2 where the appearance band of Prx 7 under treatment with $\mathrm{Pb}, \mathrm{Cd}$ and $\mathrm{Ni}$ and in Brassica nigra could be considered as a potential marker for $\mathrm{Pb}, \mathrm{Cd}$ and $\mathrm{Ni}$ tolerance.

An increase in peroxidase activity probably represents an induced protective reaction delaying senescence (Birecka et al., 1977). Since, as we know the importance of peroxidase isoenzyme to catalyze the reaction that protects the plants, against damage by free radicals. Populations showing low peroxidase activity indicated that it may not adapt them at wider range because plants may lose the permeability of membrane and proceed toward the end of life due to the harmful action of free radicals. Lipid of membranes where a peroxidation of 
unsaturated fatty acids takes place is main cellular components susceptible to damage by free radicals (Monk et al., 1989).

\section{SDS Protein Electrophoresis}

Electrophoretic analysis was carried out using SDS - PAGE for water soluble protein fraction and was stained to detect the whole protein banding pattern SDS - PAGE was achieved to screen the water soluble leaf protein extracted from the two species of the Indian mustard Brassica juncea and Brassica nigra under the treatments of heavy metals $(\mathrm{Pb}, \mathrm{Cd}$, and $\mathrm{Ni})$ and control. The protein banding patterns showed a maximum number of 20 bands which were characterized with molecular weights (MW) ranging from 116 to 12.5 KDa, and shown in Figure 3 and 4 and Tables 10 and 11.

Concerning protein banding pattern treated of Brassica juncea for the heavy metals $(\mathrm{Pb}, \mathrm{Cd}$, and $\mathrm{Ni}$ ) are shown in Table 10 and Figure 3. The control without any treatment has 15 bands ranging from 116 to $14 \mathrm{KDa}$. The treatment with $100 \mathrm{ppm} \mathrm{Pb}$ metal showed 15 bands ranging from 116 to $14 \mathrm{KDa}$, and also the treatment with $200 \mathrm{ppm} \mathrm{Pb}$ showed 15 bands ranging from 116 to $14 \mathrm{KDa}$. For the treatment with $400 \mathrm{ppm} \mathrm{Pb}$ showed 13 bands ranging from 116 to $14 \mathrm{KDa}$. On other hand the treatment with $10 \mathrm{ppm} \mathrm{Cd}$ exhibited 16 bands which ranged from 116 to $12.5 \mathrm{KDa}$, and also the treatment with $20 \mathrm{ppm} \mathrm{Cd}$ showed 12 bands ranging from 116 to 14 $\mathrm{KDa}$. For the treatment with $40 \mathrm{ppm} \mathrm{Cd}$ showed 12 bands ranging from 116 to 14 $\mathrm{KDa}$. On other hand the treatment with 20 ppm Ni exhibited 12 bands which ranged from 116 to $14 \mathrm{KDa}$, and also the treatment with 50 and 150 ppm Ni showed 12 bands ranging from 116 to $14 \mathrm{KDa}$, The band with MW 59, 39.1 and 16.2 KDa was found in the control and the treatment of 100 and 200 ppm $\mathrm{Pb}$ only.
Concerning protein banding pattern treated of Brassica nigra for the three heavy metals $(\mathrm{Pb}$, $\mathrm{Cd}$, and Ni) are shown in Table 11 and Figure 4. The control without any treatment has 14 bands ranging from 116 to $12.5 \mathrm{KDa}$. The treatment with $100 \mathrm{ppm} \mathrm{Pb}$ showed 16 bands ranging from 116 to $12.5 \mathrm{KDa}$, also the treatment with $200 \mathrm{ppm} \mathrm{Pb}$ showed 16 bands ranging from 116 to $12.5 \mathrm{KDa}$. Treatment with $400 \mathrm{ppm} \mathrm{Pb}$ showed 15 bands ranging from 116 to $12.5 \mathrm{KDa}$. On other hand the treatment with 10 ppm Cd exhibited 13 bands which ranged from 116 to $14 \mathrm{KDa}$, also the treatment with $20 \mathrm{ppm}$ Cd showed 12 bands ranging from 116 to $14 \mathrm{KDa}$, and also the treatment with 40 ppm Cd showed 13 bands ranging from 116 to $12.5 \mathrm{KDa}$. While, the treatment with 20 ppm Ni exhibited 14 bands which ranged from 116 to $12.5 \mathrm{KDa}$, also the treatment with 50 and $150 \mathrm{ppm} \mathrm{Ni}$ showed 13 bands ranging from 116 to $12.5 \mathrm{KDa}$. The band with MW 29.8 KDa which was present in $\mathrm{Pb}$ treatments except the control can be considered as potential markers associated with lead tolerance under treatment. While, the band with MW 17.5 KDa which was present in all treatments except the control can be considered as potential markers associated with heavy metals tolerance under treatment.

In general, protein bands which induced in SDS-PAGE banding patterns of the two species of the Indian mustard after treatment with three heavy metals ( $\mathrm{Pb}, \mathrm{Cd}$ and $\mathrm{Ni}$ ). Meanwhile, these bands were absent from the control. This clearly suggests that these protein bands might represent an important enzyme and or structural protein that could be involved either directly or indirectly in the process of heavy metals tolerance of Indian mustard plants. The excess of toxic heavy metal ions induces several cellular stress responses and damage to different cellular components such as membranes, proteins and DNA (Waisberg et al., 2003 and Jimi et al., 
2004). SDS-PAGE for total soluble proteins and isozyme analysis revealed moderate and moderate to high degree of polymorphism, respectively (Patra and Chawla, 2010), studied Eighteen traditional and improved basmati rice (Oryza sativa L.) varieties for morphological descriptors, total soluble proteins as biochemical markers for determining distinctive features.

Gene expression and Gene screening analysis

\section{RT-PCR and PCR}

cDNA of Glutathione GSH gene which might be induced after treatment with heavy metals was amplified from the two Indian mustard genotypes (Brassica juncea and Brassica nigra) after treatment with heavy metals; $\mathrm{Cd}$, $\mathrm{Ni}$ and $\mathrm{Pb}$. Many strategies have been conducted to isolate genes from plants. All techniques for gene isolation exploit one or more of the characteristics that define genes. Some techniques may permit the isolation of genes from any plant, while others are only applicable to one or few. Isolation of plant genes can be done via construction of cDNA library and protein purification. Based on the mentioned clues our was to take advantage of the heavy metal tolerant genotype of Indian mustard plants and to use it for identifying one of the heavy metal tolerance genes using RT-PCR .Pure preparations of the isolated total RNA were found to have 260/280 ratio between 1.8 and 2.0 RNA integrity was examined on $1.2 \%$ agarose-formaldehyde denaturing gels before proceeding in RTPCR. The total RNA $(2 \mu \mathrm{g}$.) showed sharp and clear 28S and 18S rRNA bands. This indicates that the total (poly A-RNA) isolated for both Brassica juncea and Brassica nigrahave no serious signs of degradation.

The expression activity was detected for glutathione GSH gene from the two species (B. juncea and B. nigra) using RT-PCR. The RT-PCR product of GSH gene of Brassica juncea and Brassica nigra treatment with heavy metals separated at about $240 \mathrm{bp}$ on the $1.5 \%$ agrose gel. Signals intensities of the separated fragment were different and the band intensity will be indicating the variation in GSH gene expression as a response to different treatments with heavy metals.

Table.1 Analysis of variance for final germination percentage, germination index, root length, shoot length and root/shoot ratio affected by $\mathrm{Pb}$.

\begin{tabular}{|c|c|c|c|c|c|c|}
\hline S.O.V & df & $\begin{array}{c}\text { Germination } \\
\text { percentage } \\
\text { (FGP) }\end{array}$ & $\begin{array}{l}\text { Germination } \\
\text { index } \\
\text { (GI) }\end{array}$ & $\begin{array}{c}\text { Root } \\
\text { length } \\
(\mathbf{c m})\end{array}$ & $\begin{array}{l}\text { Shoot } \\
\text { length } \\
\text { (cm) }\end{array}$ & $\begin{array}{c}\text { Root/Shoot } \\
\text { ratio }\end{array}$ \\
\hline Replication & 2 & $3.215^{\mathrm{ns}}$ & $0.0001^{\mathrm{ns}}$ & $0.002^{\mathrm{ns}}$ & $0.284^{\mathrm{ns}}$ & $2.044^{\mathrm{ns}}$ \\
\hline Genotypes & 2 & $205.704^{* * *}$ & $0.017^{* *}$ & $2.604^{* *}$ & $7.893^{* *}$ & $175.329^{* *}$ \\
\hline Treatments & 3 & $614.414^{* *}$ & $0.070^{* *}$ & 391.523 & 195.902 & 37990.940 \\
\hline $\mathrm{G} \times \mathrm{T}$ & 3 & $24.404^{* *}$ & $0.003^{* *}$ & $2.738^{* *}$ & $3.195^{* *}$ & $200.603^{\text {** }}$ \\
\hline Error & 24 & 4.534 & 0.001 & 0.081 & 0.133 & 17.410 \\
\hline
\end{tabular}

ns: Not significant; *, $* *$ : Significant at $5 \%$ and $1 \%$, respectively. 
Table.2 Mean performance of Lead for final germination percentage, germination index, root length, shoot length and root/shoot ratio of the twelve rice cultivars.

\begin{tabular}{|l|l|l|l|l|l|}
\hline \multicolumn{1}{|c|}{ Genotypes } & $\begin{array}{c}\text { Germination } \\
\text { percentage } \\
\text { (FGP) }\end{array}$ & $\begin{array}{c}\text { Germination } \\
\text { index } \\
\text { (GI) }\end{array}$ & $\begin{array}{c}\text { Root } \\
\text { length } \\
\text { (cm) }\end{array}$ & $\begin{array}{c}\text { Shoot } \\
\text { length } \\
\text { (cm) }\end{array}$ & $\begin{array}{c}\text { Root/Shoot } \\
\text { ratio }\end{array}$ \\
\hline Brassica juncea & $91.000^{\mathrm{a}}$ & $0.968^{\mathrm{a}}$ & $2.933^{\mathrm{a}}$ & $7.250^{\mathrm{a}}$ & $33.481^{\mathrm{a}}$ \\
\hline Brassica nigra & $90.333^{\mathrm{ab}}$ & $0.0 .943^{\mathrm{ab}}$ & $2.450^{\mathrm{ab}}$ & $6.350^{\mathrm{b}}$ & $29.456^{\mathrm{ab}}$ \\
\hline
\end{tabular}

Means followed by the same latter in each column or significantly different by the least significant at p 0.05 according to Duncan's test.

Table.3 Mean performance for final germination percentage, germination index, root length, shoot length and root/shoot ratio affected by $\mathrm{Pb}$ application levels.

\begin{tabular}{|l|l|l|l|l|l|}
\hline Treatment & $\begin{array}{l}\text { Germination } \\
\text { percentage } \\
(\text { FGP) }\end{array}$ & $\begin{array}{l}\text { Germination } \\
\text { index } \\
(\text { GI) }\end{array}$ & $\begin{array}{l}\text { Root } \\
\text { length } \\
(\mathbf{c m})\end{array}$ & $\begin{array}{l}\text { Shoot } \\
\text { length } \\
(\mathbf{c m})\end{array}$ & $\begin{array}{l}\text { Root/Shoot } \\
\text { ratio }\end{array}$ \\
\hline Control & $91.889^{\mathrm{a}}$ & $1.000^{\mathrm{a}}$ & $7.297^{\mathrm{a}}$ & $9.667^{\mathrm{a}}$ & $75.449^{\mathrm{a}}$ \\
\hline $100 \mathrm{ppm}$ & $86.833^{\mathrm{b}}$ & $0.948^{\mathrm{b}}$ & $2.158^{\mathrm{b}}$ & $7.450^{\mathrm{b}}$ & $29.499^{\mathrm{b}}$ \\
\hline $200 \mathrm{ppm}$ & $84.611^{\mathrm{c}}$ & $0.922^{\mathrm{c}}$ & $0.350^{\mathrm{c}}$ & $5.758^{\mathrm{c}}$ & $6.145^{\mathrm{c}}$ \\
\hline $400 \mathrm{ppm}$ & $82.194^{\mathrm{d}}$ & $0.897^{\mathrm{d}}$ & $0.292^{\mathrm{c}}$ & $4.231^{\mathrm{d}}$ & $6.937^{\mathrm{c}}$ \\
\hline
\end{tabular}

Means followed by the same latter in each column or significantly different by the least significant at $\mathrm{p} 0.05$ according to Duncan's test.

Table.4 Analysis of variance for final germination percentage, germination index, root length, shoot length and root/shoot ratio affected by $\mathrm{Cd}$.

\begin{tabular}{|l|c|c|c|c|c|c|}
\hline \multicolumn{1}{|c|}{ S.O.V } & df & $\begin{array}{c}\text { Germination } \\
\text { percentage } \\
(\text { FGP) }\end{array}$ & $\begin{array}{c}\text { Germination } \\
\text { index } \\
(\mathbf{G I})\end{array}$ & $\begin{array}{c}\text { Root } \\
\text { length } \\
(\mathbf{c m})\end{array}$ & $\begin{array}{c}\text { Shoot } \\
\text { length } \\
(\mathbf{c m})\end{array}$ & $\begin{array}{c}\text { Root/Shoot } \\
\text { ratio }\end{array}$ \\
\hline Replication & 2 & $0.444^{\mathrm{ns}}$ & $0.006^{\mathrm{ns}}$ & $0.057^{\mathrm{ns}}$ & $0.001^{\mathrm{ns}}$ & $9.337^{\mathrm{ns}}$ \\
\hline Genotypes & 1 & $438.310^{* *}$ & $0.062^{* *}$ & $1.872^{* *}$ & $5.555^{* *}$ & $183.429^{* *}$ \\
\hline Treatments & 3 & $3782.840^{* *}$ & $0.410^{* *}$ & $386.433^{* *}$ & $275.628^{* *}$ & $36730.476^{* *}$ \\
\hline G x T & 3 & $284.759^{* *}$ & $0.038^{* *}$ & $2.575^{* *}$ & $2.094^{* *}$ & $266.640^{* *}$ \\
\hline Error & 24 & $4.48^{*}$ & $0.006^{*}$ & $0.072^{*}$ & 0.125 & 22.369 \\
\hline
\end{tabular}

ns: Not significant; *,** : Significant at $5 \%$ and $1 \%$, respectively. 
Table.5 Mean performance of Cadmium for final germination percentage, germination index, root length, shoot length and root/shoot ratio of the twelve rice cultivars.

\begin{tabular}{|l|l|l|l|l|l|}
\hline Genotypes & $\begin{array}{l}\text { Germination } \\
\text { percentage } \\
\text { (FGP) }\end{array}$ & $\begin{array}{l}\text { Germinati } \\
\text { on index } \\
\text { (GI) }\end{array}$ & $\begin{array}{l}\text { Root } \\
\text { length } \\
\text { (cm) }\end{array}$ & $\begin{array}{l}\text { Shoot } \\
\text { length } \\
\text { (cm) }\end{array}$ & $\begin{array}{l}\text { Root/Shoo } \\
\text { t ratio }\end{array}$ \\
\hline Brassica juncea & $84.083^{\text {ab }}$ & $0.972^{\mathrm{a}}$ & $3.033^{\mathrm{a}}$ & $5.942^{\mathrm{b}}$ & $35.240^{\mathrm{a}}$ \\
\hline Brassica nigra & $84.500^{\mathrm{b}}$ & $0.851^{\mathrm{b}}$ & $2.442^{\mathrm{b}}$ & $6.850^{\mathrm{a}}$ & $25.546^{\mathrm{b}}$ \\
\hline
\end{tabular}

Means followed by the same latter in each column or significantly different by the least significant at p 0.05 according to Duncan's test.

Table.6 Mean performance for final germination percentage, germination index, root length, shoot length and root/shoot ratio affected by Cd application levels.

\begin{tabular}{|l|l|l|l|l|l|}
\hline Treatment & $\begin{array}{l}\text { Germination } \\
\text { percentage } \\
(\text { FGP) }\end{array}$ & $\begin{array}{l}\text { Germination } \\
\text { index (GI) }\end{array}$ & $\begin{array}{l}\text { Root } \\
\text { length } \\
(\mathbf{c m})\end{array}$ & $\begin{array}{l}\text { Shoot } \\
\text { length } \\
(\mathbf{c m})\end{array}$ & $\begin{array}{l}\text { Root/Shoot } \\
\text { ratio }\end{array}$ \\
\hline Control & $91.889^{\mathrm{a}}$ & $1.000^{\mathrm{a}}$ & $7.297^{\mathrm{a}}$ & $9.667^{\mathrm{a}}$ & $75.449^{\mathrm{a}}$ \\
\hline $10 \mathrm{ppm}$ & $87.528^{\mathrm{b}}$ & $0.929^{\mathrm{b}}$ & $2.053^{\mathrm{b}}$ & $4.878^{\mathrm{c}}$ & $43.863^{\mathrm{b}}$ \\
\hline $20 \mathrm{ppm}$ & $84.194^{\mathrm{c}}$ & $0.919^{\mathrm{b}}$ & $0.533^{\mathrm{c}}$ & $5.278^{\mathrm{b}}$ & $10.506^{\mathrm{c}}$ \\
\hline $40 \mathrm{ppm}$ & $68.361^{\mathrm{d}}$ & $0.749^{\mathrm{c}}$ & $0.236^{\mathrm{d}}$ & $3.172^{\mathrm{d}}$ & $7.654^{\mathrm{d}}$ \\
\hline
\end{tabular}

Means followed by the same latter in each column or significantly different by the least significant at $\mathrm{p} 0.05$ according to Duncan's test.

Table.7 Analysis of variance for final germination percentage, germination index, root length, shoot length and root/shoot ratio affected by $\mathrm{Ni}$

\begin{tabular}{|c|c|c|c|c|c|c|}
\hline S.O.V & df & $\begin{array}{l}\text { Germination } \\
\text { percentage } \\
\text { (FGP) }\end{array}$ & $\begin{array}{l}\text { Germination } \\
\text { index } \\
\text { (GI) }\end{array}$ & $\begin{array}{l}\text { Root } \\
\text { length } \\
(\mathrm{cm}) \\
\end{array}$ & $\begin{array}{l}\text { Shoot } \\
\text { length } \\
(\mathrm{cm}) \\
\end{array}$ & $\begin{array}{l}\text { Root/Shoot } \\
\text { ratio }\end{array}$ \\
\hline Replication & 2 & $1.799^{\mathrm{ns}}$ & $0.001^{\mathrm{ns}}$ & $0.051^{\mathrm{ns}}$ & $0.051^{\mathrm{ns}}$ & $32.565^{\mathrm{ns}}$ \\
\hline Genotypes & 1 & $1127.035^{\text {** }}$ & $0.195^{* *}$ & $2.504^{* *}$ & $3.944^{* *}$ & $1614.818^{* *}$ \\
\hline Treatments & 3 & $29967.30^{* * *}$ & $3.467^{\text {** }}$ & $364.392^{\text {** }}$ & $719.956^{\text {** }}$ & $39857.13^{\text {*** }}$ \\
\hline $\mathrm{G} \times \mathrm{T}$ & 3 & $759.453^{\text {*** }}$ & $0.081^{* *}$ & $2.470^{* *}$ & $1.902^{* *}$ & $1312.858^{* *}$ \\
\hline Error & 24 & 3.054 & 0.0001 & 0.060 & 0.054 & 27.708 \\
\hline
\end{tabular}

ns: Not significant; $*$, ** : Significant at $5 \%$ and $1 \%$, respectively. 
Table.8 Mean performance of Nickel for final germination percentage, germination index, root length, shoot length and root/shoot ratio of the twelve rice cultivars.

\begin{tabular}{|l|l|l|l|l|l|}
\hline \multicolumn{1}{|c|}{ Genotypes } & $\begin{array}{c}\text { Germination } \\
\text { percentage } \\
\text { (FGP) }\end{array}$ & $\begin{array}{c}\text { Germination } \\
\text { index } \\
\text { (GI) }\end{array}$ & $\begin{array}{c}\text { Root } \\
\text { length } \\
\text { (cm) }\end{array}$ & $\begin{array}{c}\text { Shoot } \\
\text { length } \\
\text { (cm) }\end{array}$ & $\begin{array}{c}\text { Root/Shoot } \\
\text { ratio }\end{array}$ \\
\hline Brassica juncea & $76.833^{\mathrm{a}}$ & $0.887^{\mathrm{a}}$ & $2.958^{\mathrm{a}}$ & $3.836^{\mathrm{ab}}$ & $41.789^{\mathrm{a}}$ \\
\hline Brassica nigra & $75.000^{\mathrm{b}}$ & $0.823^{\mathrm{b}}$ & $2.400^{\mathrm{b}}$ & $3.963^{\mathrm{a}}$ & $22.167^{\mathrm{b}}$ \\
\hline
\end{tabular}

Means followed by the same latter in each column or significantly different by the least significant at $\mathrm{p} 0.05$ according to Duncan's test.

Table.9 Mean performance for final germination percentage, germination index, root length, shoot length and root/shoot ratio affected by Ni application levels.

\begin{tabular}{|l|l|l|l|l|l|}
\hline Treatment & $\begin{array}{l}\text { Germination } \\
\text { percentage } \\
\text { (FGP) }\end{array}$ & $\begin{array}{l}\text { Germination } \\
\text { index (GI) }\end{array}$ & $\begin{array}{l}\text { Root } \\
\text { length } \\
\text { (cm) }\end{array}$ & $\begin{array}{l}\text { Shoot } \\
\text { length } \\
(\mathbf{c m})\end{array}$ & $\begin{array}{l}\text { Root/Shoot } \\
\text { ratio }\end{array}$ \\
\hline Control & $91.889^{\mathrm{a}}$ & $1.000^{\mathrm{a}}$ & $7.297^{\mathrm{a}}$ & $9.667^{\mathrm{a}}$ & $75.449^{\mathrm{a}} *$ \\
\hline $20 \mathrm{ppm}$ & $88.833^{\mathrm{b}}$ & $0.969^{\mathrm{b}}$ & $1.361^{\mathrm{b}}$ & $3.014^{\mathrm{b}}$ & $48.473^{\mathrm{b}}$ \\
\hline $50 \mathrm{ppm}$ & $63.556^{\mathrm{c}}$ & $0.703^{\mathrm{c}}$ & $1.158^{\mathrm{c}}$ & $0.374^{\mathrm{c}}$ & $18.282^{\mathrm{c}}$ \\
\hline $150 \mathrm{ppm}$ & $29.611^{\mathrm{d}}$ & $0.330^{\mathrm{d}}$ & $0.433^{\mathrm{d}}$ & $0.010^{\mathrm{d}}$ & $0.00^{\mathrm{d}}$ \\
\hline
\end{tabular}

Means followed by the same latter in each column or significantly different by the least significant at p 0.05 according to Duncan's test.

Table.10 Effect of heavy metals $(\mathrm{Cd}, \mathrm{Ni}$ and $\mathrm{Pb})$ and control on the level of GSH gene transcription in $B$. juncea using RT-PCR.

\begin{tabular}{|l|c|c|c|c|}
\hline MT 1 Kb & Control & $\mathrm{Pb}$ & $\mathrm{Ni}$ & $\mathrm{Cd}$ \\
\hline $240 \mathrm{bp}$ & 1 fold & 1.4 fold & 3.5 fold & 5.3 fold \\
\hline
\end{tabular}

Fig.1 Peroxidase isozyme pattern Brassica nigra genotype under treatment with heavy metals.

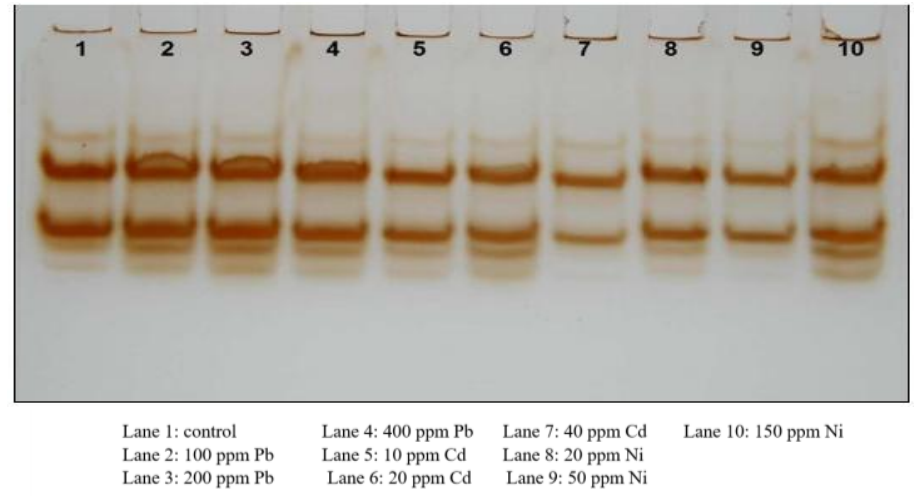


Fig.2 Peroxidase isozyme pattern Brassica nigra genotype under treatment with heavy metals

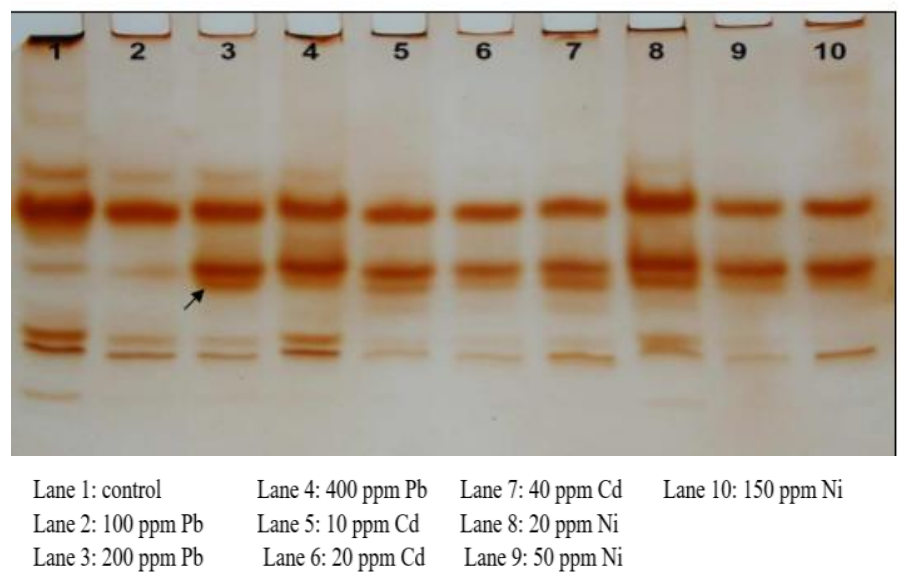

Fig.3 SDS-PAGE protein banding pattern for Brassica juncea genotype under treatment with heavy metals.

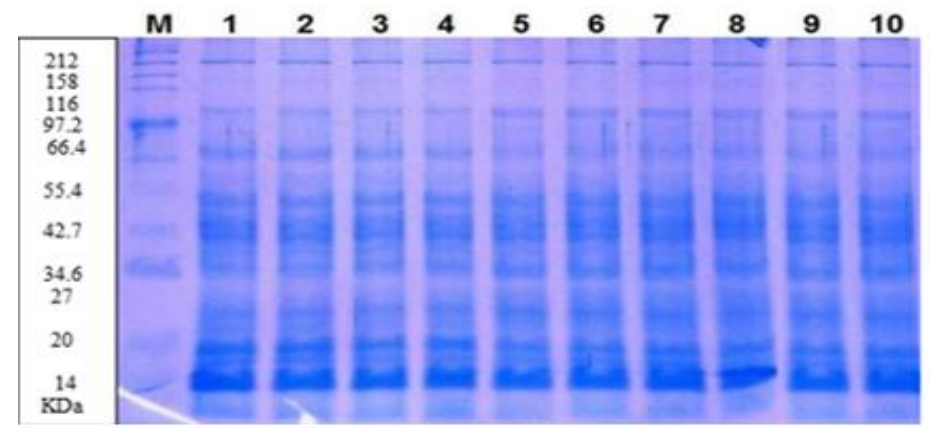

Lane 1: control - Lane 2: $100 \mathrm{ppm} \mathrm{Pb}$ - Lane 3: $200 \mathrm{ppm} \mathrm{Pb}$ - Lane 4: 400 ppm Pb - Lane 5:10 ppm Cd - Lane 6: 20 ppm Cd Lane 7: 40 ppm Cd - Lane 8: 20 ppm Ni - Lane 9: 50 ppm Ni Lane 10: $150 \mathrm{ppm} \mathrm{Ni}$

Fig.4 SDS-PAGE protein banding pattern for Brassica nigra genotype under treatment with heavy metals

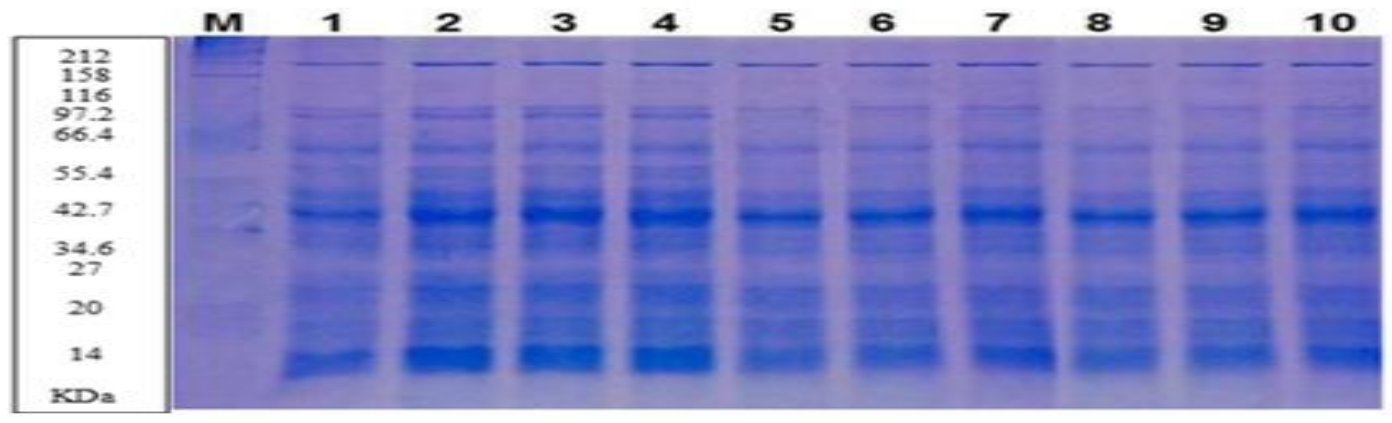

Lane 1: control - Lane 2: $100 \mathrm{ppm} \mathrm{Pb}$ - Lane 3: $200 \mathrm{ppm} \mathrm{Pb}$

- Lane 4: 400 ppm Pb - Lane 5:10 ppm Cd - Lane 6: 20 ppm Cd Lane 7: 40 ppm Cd - Lane 8: 20 ppm Ni - Lane 9: 50 ppm Ni Lane 10: 150 ppm Ni 
Fig.5 Agrose gel for RT-PCR amplified fragment on RNA isolated from leaves Indian mustard under treatment with heavy metals

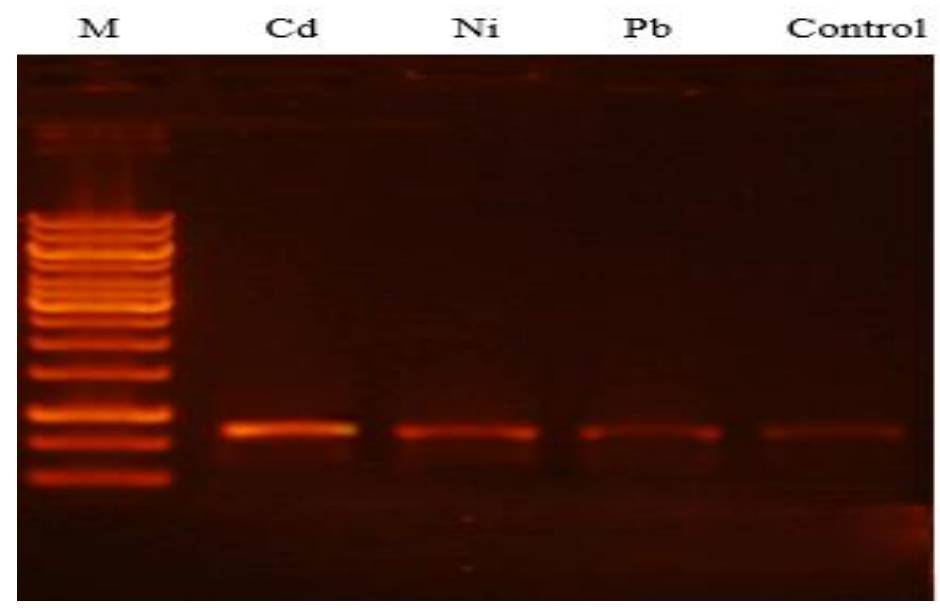

Fig.6 Database sequences aligned to the query sequence

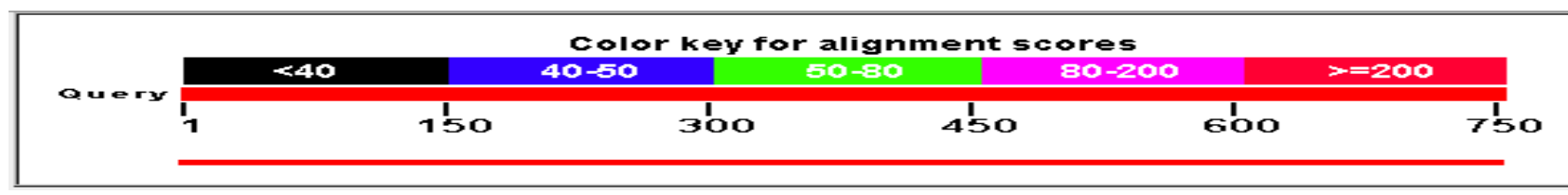

Sequences producing significant alignments:

Select: All None Selected:0

\begin{tabular}{|c|c|c|c|c|c|c|c|c|}
\hline \multicolumn{9}{|c|}{ 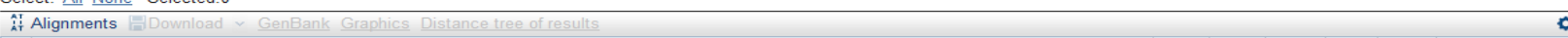 } \\
\hline & Description & $\begin{array}{l}\text { Max } \\
\text { score }\end{array}$ & $\begin{array}{l}\text { Total } \\
\text { score }\end{array}$ & $\begin{array}{l}\text { Quer } \\
\text { cove }\end{array}$ & $\underset{\text { valu }}{E}$ & & dent & Accession \\
\hline$\square$ & Aspergillus niger CBS 513.88 MFS transporter. mRNA & 1397 & 1397 & $100 \%$ & 0. & & $100 \%$ & XM 001402501.3 \\
\hline
\end{tabular}

Query 1 ATGAACGGCAATCCATCCTCTTCATCAGCTACAGAGACAAACGCCGCCGATCTAGAAAAA 60

| || || || ||||||||||||||||||||||||||||||||||||||||||||||||||||

Sbjet 1 ATGAACGgCAATCCATCCTCTTCATCAGCTACAGAGACAAACGCCGCCGATCTAGAAAAA 60

Query 61 GAGCCGAACCAAGATGCACCACCTAGGCTGGAGGTATTTTCAGTCTTCACAGTCAACCAG 120

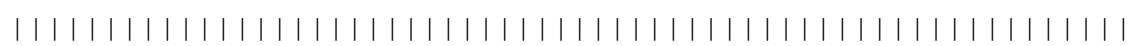

Sbjet 61 GAGCCGAACCAAGATGCACCACCTAGGCTGGAGGTATTTTCAGTCTTCACAGTCAACCAG 120

Query 121 AAGAGAGCCATGGTGGCGACCGGCTCAATGGCGAGCTTTTTCTCGCCTTTGTCTTCAAGC 180

111111111111111111111111111111111111111111111111111111111111111111

Sbjet 121 AAGAGAGCCATGGTGGCGACCGGCTCAATGGCGAGCTTTtTCTCGCCTTTGTCTTCAAGC 180

Query 181 ATCTACTTCCCTGCCATGGACACGATCGCAACAGCGCTGAATGTCTCCACATCCAAGATT 240

1111111111111111111111111111111111111111111111111111111111111111111

Sbjet 181 ATCTACTTCCCTGCCATGGACACGATCGCAACAGCGCTGAATGTCTCCACATCCAAGATT 240

Query 241 GATTTGACTGTCACGACCTACCTCATAATGCAAGGCATAGCTCCCATGTTGATCGCCGGA 300

11111111111111111111111111111111111111111111111111111111111111111

Sbjet 241 GATTTGACTGTCACGACCTACCTCATAATGCAAGGCATAGCTCCCATGTTGATCGCCGGA 300

Query 301 TTCTCAGACACAGCCGGCAGACGTCCCGCCTACATAATCTGCTTCACCGTCTATATCGCC 360

11111111111111111111111111111111111111111111111111111111111111111 
Int.J.Curr.Microbiol.App.Sci (2017) 6(1): 447-461

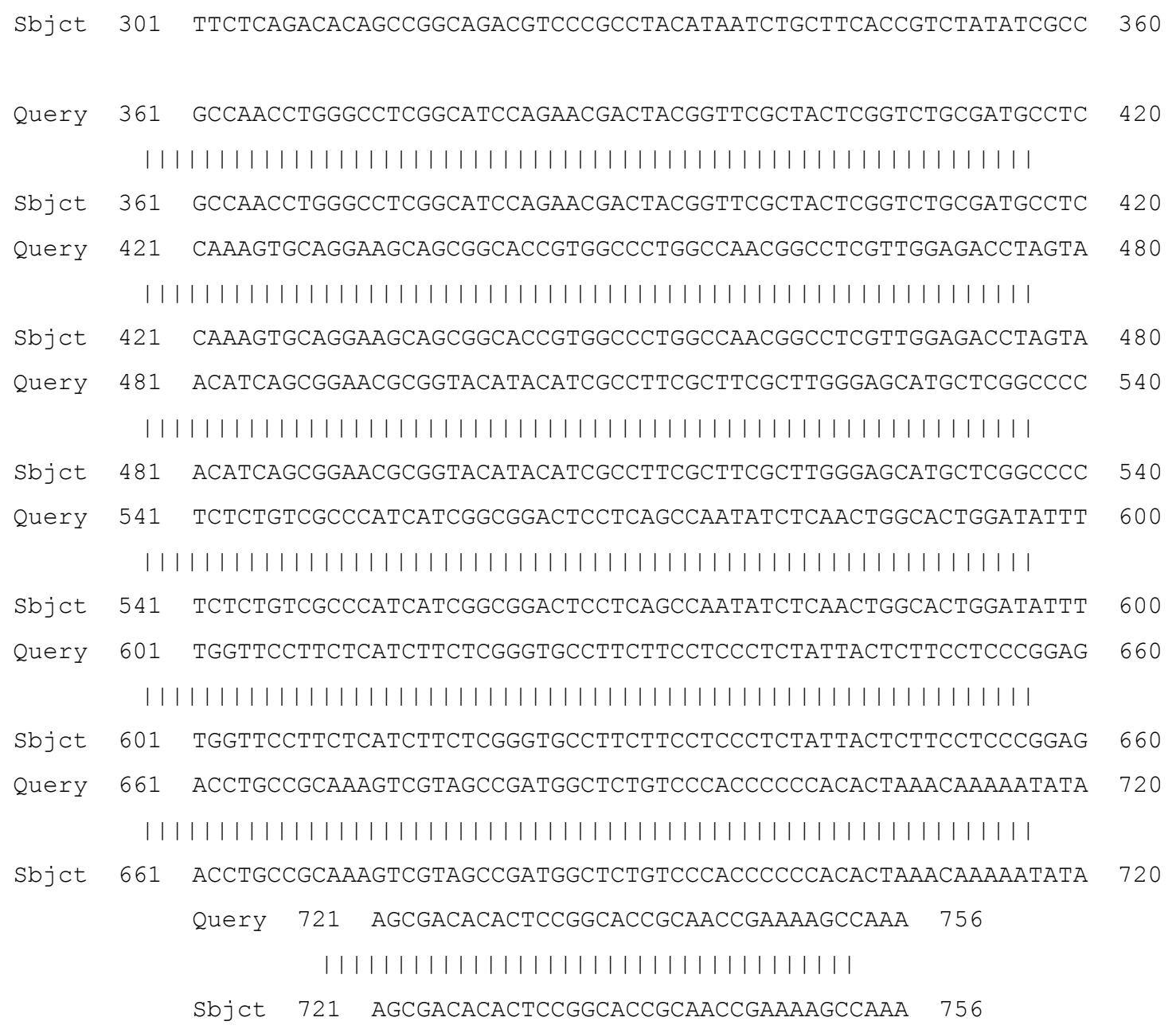

The untreated control plants (C) of $B$. junceaand $B$. nigra did not show any expression of GSH gene, meanwhile the gene up-regulated in varied levels as a response to stress, is shown in figure 5 and table 12 .

Table (12) show the effect of treatment on the level of GSH hence, the highest expression as 5.3 fold of GSH was obtained in treatment with $\mathrm{Cd}$, and 3.5 fold of GSH was obtained in treatment with $\mathrm{Ni}$ in B. juncea. While 1.4 fold was obtained in treatments $\mathrm{Pb}$. The same results were obtained with treatment in $B$. nigra. These results are in agreement with those obtained by Vido et al., (2001) who reported that (GSH) is strongly increased in response to cadmium treatment, Schützendübel and Polle, (2002), GSH is apparently a critical step in cadmium sensitivity since plants with improved capacities for GSH synthesis displayed higher $\mathrm{Cd}$ tolerance. These results also disagreement with those obtained by Liang et al., (1999), In the presence of $\mathrm{Cd}$, the GS enzyme is rate limiting for the biosynthesis of glutathione and phytochelatins.

\section{Sequence analysis of GSH gene}

A multiple sequence alignment of GSH nucleotide sequence (current study) was carried out with GSH sequences published in the GenBank. Sequence comparison showed that GSH of the current study had sequence homology of about $100 \%$ with other GHS isolates, mRNA sequence homology of about 100\% with Aspergillus Niger isolates. These results are in agreement with those obtained. 
An overview of the Gene bank sequences is shown in figure 6.

\section{References}

Bradford, M.M. 1976. Rapid and sensitive method for the quantitation of microgram quantities of protein utilizing the principle of protein-dye binding. Analyt. Biochem., 72: 248-254.

Clemens, S. 2001. Molecular mechanisms of plant metal tolerance and homeostasis. Planta, 212(4): 475-86.

Heyno, E., C. Klose and A. Krieger-Liszkay. 2008. Origin of cadmium-induced reactive oxygen species production: mitochondrial electron transfer versus plasma membrane NADPH oxidase. New Phytol., 179: 687-699.

Kovacik, J., B. Klejdus, J. Hedbavny and M. Backor. 2010. Effect of copper and salicylic acid onphenolic metabolites and free amino acids in Scenedesmusquadricauda (Chlorophyceae. Plant Sci., 178(3): 307-11.

Laemmli, U.K. 1970. Cleavage of structure proteins during assembly of head bacteriophage T4. Nature (London), 227:680-685.

Liang, Z.Y., E.A. Pilon-Smits, L. Jouanin and N. Terry. 1999. Overexpression of glutathione Synthetase in Indian mustard enhances cadmium accumulation and tolerance. Plant Physiol., 119(1): 73-80.

Long, Li., Huilan, Yi. 2012. Effect of sulfur dioxide on ROS production, gene expression and antioxidant enzyme activity in Arabidopsis plants. Plant Physiol. Biochem., Volume 58, Pages 46-53.

Meharg, A.A. 1993. Integrated tolerance mechanisms: constitutive and adaptive plant response to elevated metal concentrations in the environment. Plant Cell Environ., 17:
989-993.

Memon, A.R. and P. Schröder. 2009. Implication of metal accumulation mechanisms tophytoremediation. Environ. Sci. Pol. Res. (ESPR), 16: 162175.

Mendoza-Cozatl, D.G. and R. MorenoSanchez. 2005. $\mathrm{Cd} 2+$ transport and storage in the chloro-plast of Euglenagracilis. Biochim. Biophys. Acta, 1706(1-2):88-97.

Mendoza-Cozatl, D., H. Loza-Tavera., A. Hernandez-Navarro, R. MorenoSanchez. 2005. Sulfur assimilation and glutathione metabolism under cadmium stress in yeast, protists and plants. FEMS Microbiol. Rev., 29: 653671.

Mohamed, A.A., A. Castagna, A. Ranieri and L. Sanità di Toppi. 2012. Cadmium tolerance in Brassica juncearoots and shoots is affected by antioxidant status and phytochelatin biosynthesis. Plant Physiol. Biochem., Pp. 1-8

Peralta-Videa, J.R., M.L. Lopez, M. Narayan, G. Saupe and J. Gardea-Torresdey. 2009. The biochem-istry of environmental heavy metal uptake by plants: implications for the foodchain. Int. J. Biochem. Cell Biol., 41(8-9): 1665-77.

Pinto, E., T.C.S. Sigaud-Kutner, M.A.S. Leitao, O.K. Okamoto, D. Morse and P. Colepicolo. 2003. Heavymetalinduced oxidative stress in algae. $J$. Phycol., 39(6): 1008-18.

Qian, H., J. Li., L. Sun., W. Chen., G. D. Sheng., W. Liu and Z. Fu. 2009. Combined effect of copper and cadmium on Chlorella vulgaris growth and photosynthesis-related gene transcription. Aquat. Toxicol., 94: 5661.

Raskin, I., R.D. Smith and D.E. Salt. 1997. Phytoremediation of metals: using plants to remove pollutants from the 
environment, Curr. Opin. Biotechnol., 8: 221-226.

Romero-Puertas, M.C., M. RodriguezSerrano., F.J. Corpas., M. Gomez., L. A. Del Rio and L.M. Sandalio. 2004. Cadmium-induced subcellular accumulation of $\mathrm{O} \cdot 2-$ and $\mathrm{H} 2 \mathrm{O} 2$ in pea leaves. Plant Cell Environ., 27: 11221134.

Salt, D.E., R.D. Smith and I. Raskin. 1998. Phyto remediation. Annual Review of Plant Physiol. Plant Mol. Biol., 49: 643-668.

Schützendübel and Polle. 2002. Plant responses to abiotic stresses: heavy metal-induced oxidative stress and protection by mycorrhization. $J$. Experimental Bot., 53(372): 1351-1365.

Schwitzguébel, J. P., E. Comino., N. Plata and M. Khalvati. 2011. Is phytoremediation a sustainable and reliable approach to clean-up contaminated water and soil in Alpine areas? Environ. Sci. Pollution Res. Int., 18: 842-856

Shanker, A.K., C. Cervantes., H. LozaTavera and S. Avudainayagam. 2005. Chromium toxicity in plants. Environ. Int., 31(5): 739-53.
Shanmugam, V., J.C. Lo., C.L. Wu., S.L. Wang., C.C. Lai and E.L. Connolly 2011. Differential expression and regulation of iron-regulated metal transporters in Arabidopsishalleri and Arabidopsis thaliana - the role in zinc tolerance. New Phytol., 190(1): 125-37.

Vangronsveld, J., R. Herzig., N. Weyens., J. Boulet., K. Adriaensen., Ruttens A., T. Thewys., A. Vassilev., E. Meers., E. Nehnelajova., D. van der Lelie and M. Mench. 2009. Phytoremediation of contaminated soils and groundwater: lessons from the field. Environ. Sci. Pollu. Res., 16: 765-794.

Verbruggen, N.., C. Hermansand H. Schat. 2009. Mechanisms to cope with arsenic or cadmium excess in plants. Curr. Opin. Plant Biol., 12(3): 364-72.

Vido, K., D. Spector, G. Lagniel, S. Lopez, M.B. Toledano, and J. Labarre. 2001. A Proteome Analysis of the Cadmium Response in Saccharomyces cerevisiae. J. Biol. Chem., 276(11): 8469-8474.

Waalkes, M.P. 2000. Cadmium carcinogenesis in review. J. Inorg. Biochem., 79: 241-244.

\section{How to cite this article:}

Aysam M. Fayed and Mona A. Farid. 2017. Expression of GSH Gene Related to Heavy Metals Tolerance and Accumulation in Brassica sp. Plant Genotypes. Int.J.Curr.Microbiol.App.Sci. 6(1): 447-461. doi: http://dx.doi.org/10.20546/ijcmas.2017.601.053 